\title{
Metformin - újabb adatok egy megbízható és hatékony „régi” vércukorcsökkentő készítményről
}

\author{
Winkler Gábor dr. ${ }^{1,2}$ \\ ${ }^{1}$ Szent János Kórház, II. Belgyógyászat-Diabetológia, a Semmelweis Egyetem, \\ Általános Orvostudományi Kar Oktató Osztálya, Budapest \\ ${ }^{2}$ Miskolci Egyetem, Egészségügyi Kar, Elméleti Egészségtudományi Intézet, Miskolc
}

\begin{abstract}
A metformin a 2-es típusú diabetes vércukorcsökkentő kezelésének alapgyógyszere: a hatályos kezelési irányelvek szerint ellenjavallat/intolerancia hiányában adását a betegség egész tartamában fenn kell tartani, inzulinkezelés bevezetését követően is. Az utóbbi időben mind több részlet vált ismertté hatásai molekuláris hátterét illetően, a megismeréssel párhuzamosan nőtt azonban a megválaszolásra váró újabb kérdések száma is. Az áttekintő közlemény a szer klinikai farmakológiájával és hatásspektrumával kapcsolatos már kikristályosodott, illetve újabb adatokat járja körül. Röviden kitér a hatását potenciálisan befolyásoló genetikai polimorfizmusokra és gyógyszer-interakciókra is. Orv. Hetil., 2016, 157(23), 882-891.
\end{abstract}

Kulcsszavak: metformin, farmakokinetika, farmakodinamika, molekuláris mechanizmusok, genetikai polimorfizmusok, gyógyszer-interakciók

\section{Metformin - new data of an "old", but efficient, safe and reliable antidiabetics}

\begin{abstract}
Metformin is the basic drug of antihyperglycemic therapy in type 2 diabetes: according to actual therapeutic guidelines, it should be given in the absence of contraindications or intolerance during the whole course of the disease even after the initiation of insulin therapy. Recently more and more details have been explored regarding the molecular background of its effects, however, in parallel with the enormous growing knowledge, the number of questions still waiting to be answered has also grown. This review article deals with data already crystallized as well as with details not definitely cleared up. Genetic polymorphisms as well as potential drug interactions influencing the effects of metformin are also briefly summarized.
\end{abstract}

Keywords: metformin, pharmacokinetics, pharmacodynamics, molecular mechanisms, genetic polymorphisms, potential drug interactions

Winkler, G. [Metformin - new data of an "old", but efficient, safe and reliable antidiabetics]. Orv. Hetil., 2016, $157(23), 882-891$.

(Beérkezett: 2016. március 24.; elfogadva: 2016. április 21.)

\section{Rövidítések}

5-HT3 = 5-hidroxi-triptamin-3; ADP = adenozin-difoszfát; $\mathrm{AgRP}=($ Agouti-related protein $)$ Agouti-szerü fehérje; AMP = adenozin-monofoszfát; AMPK = AMP-vel aktiválódó kináz; ATP $=$ adenozin-trifoszfát $; \quad$ CART $=($ cocaine-amphetamine retard transcript) kokain-amfetamin függő termék; CI = (confidence interval) megbízhatósági tartomány; CIN = (contrastinduced nephropathy) kontrasztanyag kiváltotta vesekároso- dás; $\mathrm{CYP}=$ citokróm P450 mikroszomális enzimrendszer; $\mathrm{DR}=($ delayed reabsorption $)$ késleltetett felszívódású gyógyszerváltozat; FDA = (Food and Drug Administration $)$ (amerikai) Élelmiszer- és Gyógyszerfelügyelet; GFR = glomerularis filtrációs ráta; GLP-1 = (glucagon-like peptide) glükagonszerü peptid-1; HIF = hypoxia indukálta faktor; ICAM = (intercellular cell adhesion molecule) intercelluláris sejtadhéziós molekula; IR = (immediate release $)$ azonnal oldódó gyógyszerválto- 
zat; $\mathrm{LKB}=$ liver kináz $\mathrm{B} ; \quad$ MATE $=$ multidrug and toxin extrusion (transporter); MiG (vizsgálat) = Metformin in Gestational Diabetes; MiG TOFU (vizsgálat) = MiG: The Offsprings Follow-Up; MOP (vizsgálat) = Metformin in Obese Nondiabetic Pregnant Women; $\mathrm{MRCCl}=($ mitochondrial respiratory chain complex-1) mitochondrialis légzési lánc komplex-1; mTOR $=($ mammalian target of rapamycin $)$ jelátviteli tényező; NPY = neuropeptid $\mathrm{Y}$; OCT $=$ organikus kation transzporter; PCOS = polycystás ovarium szindróma; $\mathrm{PMAT}=$ plazmamembrán-monoamin-transzporter; $\mathrm{POMC}=$ proopiomelanokortin; $\mathrm{pp}=$ postprandialis; PYY = peptid YY; REACH (vizsgálat $)=$ Reduction of Atherothrombosis for Continued Health; ROS $=$ reaktívoxigén-species; $\mathrm{RPF}=$ (renal plasma flow) vesekeringés; SLC $=$ (solute carrier molecule) oldottanyag-szállító (molekula); SNP = (single nucleotid polymorphism) egynukleotidos polimorfizmus; SREBPl $=($ sterol regulatory element-binding protein-1) sterolreguláló elemeket kötő fehérje-1; StAR = (steroidogenic acute regulatory protein $)$ szteroidogén akut regulátoros fehérje; T2DM $=2$-es típusú diabetes mellitus; TGF = transzformáló növekedési faktor; VCAM $=($ vascular cell adhesion molecule $)$ vascularis sejtadhéziós molekula; $\mathrm{XR}=$ (extended release $)$ elhúzódó hatóanyagkioldódású gyógyszerváltozat

Az 1950-ben elő́lllított [1] és 1957-ben forgalomba került - az FDA által csak 1995-ben „befogadott” [2] metformin a 2-es típusú cukorbetegség (T2DM) vércukorcsökkentő kezelésének alapgyógyszere. Hatékonysága és biztonságos volta alapján intolerancia/ellenjavallat hiányában a legtöbb kezelési útmutatás elsőként választandóként határozza meg [3-5].

A hatásmechanizmusával, szervezetbeli sorsával kapcsolatos ismereteinket ugyanakkor furcsa kettősség jellemzi. Egyfelól egyre részletesebben tárulnak fel felszívódásának, célszövetekbe jutásának és vércukorcsökkentő hatásának molekuláris mechanizmusai $[2,6]$; bővülnek - esetenként off label jelleggel [7] - adásának indikációs lehetőségei [8-10], szaporodnak a „pleiotrop” előnyeit alátámasztó megfigyelések [11, 12]. Másfelól, e megismerésekkel párhuzamosan, újabb megválaszolásra váró kérdések merülnek fel hatása pontos természetét illetően: Mi a magyarázata, hogy a máj- és zsírszövetben serkenti, a központi idegrendszerben viszont részben gátolja, részben serkenti az adenozin-monofoszfáttal (AMP) aktiválódó kináz (AMPK) múködését? Milyen mechanizmusok állnak az egyik, s melyek a másik hátterében [13]? Hogyan lehetséges erőteljes glykaemiás hatása viszonylag alacsony biohasznosulása mellett [14]? Milyen részesedésú a glükagonszerú peptid (glucagon like peptide - GLP) - l és peptid YY (PYY) elválasztását serkentő természete antihyperglykaemiás hatásában [15]?

Jelen munka e kérdéseket, a metformin klinikai farmakológiááával és hatásspektrumával kapcsolatos már kikristályosodott, illetve újabb adatokat - esetenként vitatott vagy csak hipotetikus felvetéseket - járja körül.

\section{A metformin farmakokinetikájának fóbb adatai}

Bár alkalmazása a klinikai gyakorlatban kizárólag orális bevitel formájában történik, vizsgálták parenteralis bejuttatásának farmakokinetikáját is. Eszerint egyszeri iv. beadását követóen plazma-féléletideje $1,7-4,5$ óra közötti - az adatok nagy szórást mutattak -, ismételt adagolásakor teljes vérben mért terminális fél életideje 9-19 óra közötti volt. Plazmakoncentrációja gyorsan csökkent. Ez, valamint a vérben mért hosszú terminális fél életideje annak következménye, hogy a plazmából viszonylag rövid idő alatt szöveti kompartmenekbe - jelentős részben a vörösvértestekbe - lép. Eliminációja 90\%-ban a vizelettel történik, a kiválasztódó mennyiség 95\%-a a beadás utáni első 8 órában mérhető [16].

Orális alkalmazásra azonnal oldódó (immediate release - IR) és elhúzódó hatóanyag-kioldódásúvá alakított változata is forgalomban van. Az IR-változat napi adagját két-háromszorra elosztva, étkezés közben javasolt bevenni. Így történő alkalmazása ugyanis ritkábbá teheti gastrointestinalis mellékhatások megjelenését. A jelenleg hozzáférhető másik formuláció elnyújtott hatását a transpyloricus passzázs késleltetését segító gélszerú massza biztosítja. E gyógyszerforma a hazai forgalmazásban az extended release, XR jelölést kapta, néhány országban slow release - SR -, „retard”, illetve „long” jelzéssel használják [16]. Az XR-változatot egy dózisban, este célszerú adagolni. E gyógyszerforma alkalmazásakor a gastrointestinalis panaszok előfordulása ritkább és általában enyhébb az IR-változatok mellett észleltnél.

A hatóanyag elnyújtott felszívódására további technológiai módosításokat - ozmotikus felszívódás késleltetését [16], mikroszféra-szerkezetet [17] - is kifejlesztettek, ezek azonban szélesebb körben nem terjedtek el. Újabb elhúzódó felszívódású változatával (delayed reabsorption - DR) biztató - fázis II - vizsgálatokat folytatnak (kifejlesztésének elméleti hátterére a késóbbiekben viszszatérünk) [14].

Felszívódása döntő részben a vékonybél proximális szakaszán történik: a gyomorból és a vastagbélből abszorpciója elhanyagolható mértékú [16]. Felszívódása nem dózisarányos, biohasznosulását - ami 50\% - a bélfalon történő átjutását segítő transzportfehérjék (l. később) telítettségi állapota határozza meg. Más szóval: a dózis növelésével a felszívódott hányad csökken. (Ez a magyarázata annak a korábbi megfigyelésnek, hogy $>2000 \mathrm{mg} / \mathrm{nap}$ adag esetén a dózis-hatás görbe ellapul. Ugyanez az oka a felszívódás individuális variabilitásának, amit számos vizsgálat is igazolt.) Vegyes összetételű táplálék felszívódását érdemben nem befolyásolja, magas zsírtartalmú étkezés azonban akár 25\%-kal csökkenheti [16].

Plazmában mért felezési ideje átlagosan 6,2 óra, teljes vérben meghatározott terminális fél életideje azonban 17,6 óra. A két adat jelentôs eltérése a vörösvértestek elhúzódó metforminfelvételével és leadásával magyaráz- 
ható. A hatóanyag egyszeri adagját követő maximális plazmakoncentráció dózisfüggően változik, 1,0-3,0 mg/l (1000-3000 ng/ml közötti), s IR-változat esetén a bevételt követő 4-6., XR-forma alkalmazásakor a 7-8. órában alakul ki $[6,18]$. (Az egyszeri dózis bevételét követően, görbe alatti területként meghatározott plazmakoncentrációt az XR-változat esetében néhány vizsgálatban valamivel nagyobbnak, a mérések többségében egyezőnek találták. Ettől eltekintve a két változat farmakokinetikája, hatékonysága egymással egyezőnek bizonyult [19].) Folyamatos adagolás esetén a steady state plazmaszint viszonylag széles tartományban, részben az alkalmazott dózis függvényében, $54-4133 \mathrm{ng} / \mathrm{ml} \mathrm{kö-}$ zött változik (másik befolyásoló tényezője az elimináció mértéke és üteme) $[6,16,18]$. Plazmafehérjékhez nem kötődik [16]. Megoszlási térfogata nagy, $654 \pm 358$ liter $[16,18]$. Clearence-e $510 \pm 120 \mathrm{ml} / \mathrm{min}$, a kreatininének több mint háromszorosa, aminek az a magyarázata, hogy eliminációja glomerularis filtráció mellett tubularis szekrécióval is történik. (Clearence-ét különböző vizsgálatok széles tartományban változónak találták. Egyes forrásokban szerepel a metformin/kreatinin clearence arányának feltüntetése is: $4,3 \pm 1,5$ [16].)

Az életkorral előrehaladva a metformin clearence-e is csökken. Megfigyelések szerint azonban a csökkenés kisebb mértékű, mint a kreatininclearence esetében, így önmagában az életkor nem korlátozó tényező [16].

Eliminációját ugyancsak kizárólag renalisan ürülő gyógyszerek gátolhatják. E tekintetben a képalkotó vizsgálatokhoz használt, a szervezetből ozmotikus diuresissel távozó jódos kontrasztanyagok a legjelentősebbek. E szerek ritka, de veszélyes szövődménye az úgynevezett kontrasztanyag indukálta akut veseelégtelenség (contrastinduced nephropathy - CIN). Nincs egyértelmü adat arra vonatkozóan, hogy ennek előfordulása metformint szedő személyek között gyakoribb-e [20], biztonságból azonban e vizsgálatok előtt 48 órával a metformin adása leállítandó és alkalmazása csak a vizsgálat szövődménymentes befejezése után 48 órával indítható újra [21]. Régebben a vesefunkció ellenőrzését is ajánlották a metformin újraindítását megelőzően, ennek korábban rendezett értéke és a vesekárosodás klinikai jeleinek hiánya esetén azonban az újabb ajánlások nem tartják feltétlenül indokoltnak [20]. A teljesség kedvéért meg kell említenünk, hogy különböző radiológiai és nefrológiai testületek állásfoglalása nem egységes a kihagyásra vonatkozóan [20], az európai és ehhez igazodóan a hazai irányelvek azonban a biztonságot szem előtt tartva ezt írják elő.

Krónikus vesemúködési zavarban, éppen a metformin kettős ürülési mechanizmusának ismeretében, az utóbbi időben némileg módosult a korábbi merev álláspont [4]. Eszerint, ha biztonságos adásának egyéb korlátozó tényezői (napi < 100 gramm szénhidrát bevitele, hypoxiás állapotok fennállása, a hepatoparenchymás enzimszintek normális felső határát $\geq 2,5$-szeresen meghaladó értékek) nem állnak fenn, $\geq 45 \mathrm{ml} / \mathrm{min}$ GFR-értékig maximum napi 1500 mg-nyi adása megengedhető. A hazai gyakor- latban a törzskönyv módosulása még csak néhány készítményváltozatnál lépett életbe, ezt a gyógyszer rendelésekor mérlegelni kell! A korlátozó feltételek között szokás a rendszeres alkoholfogyasztást is említeni, egyrészt, mert előidézi a májkárosodás kialakulását, másrészt társulhat a szükségesnél kevesebb szénhidrát fogyasztásával, harmadrészt, mert alkohol jelenléte befolyásolhatja a piroszőlősav-tejsav egyensúlyi reakció kinetikáját.

A metformin átjut a placentán. A gyógyszert terhességük alatt szedő várandósokon, terminusban, a köldökzsinórvérben mérve, méréshatár alattitól $(<5 \mathrm{ng} / \mathrm{ml})$ $1263 \mathrm{ng} / \mathrm{ml}$-ig változó vérszintet találtak. Ez utóbbi jóval alacsonyabb az átlagos anyai plazmakoncentrációnál [22]. Meg kell jegyeznünk, hogy várandósokon az átlagos plazmakoncentráció alacsonyabb az azonos napi dózist szedő nem terhes kortársakban mértnél, aminek oka a metforminclearence terhesség alatti emelkedése [16]. A terhesség középidejében ezt $723 \pm 243 \mathrm{ml} / \mathrm{min}-\mathrm{nek}$, késő terhességben $625 \pm 130 \mathrm{ml} / \mathrm{min}$-nek találták, amit a terhesség alatti vesekeringés (renal plasma flow - RPF) és következményesen a glomerularis filtráció emelkedése mellett a tubularis szekréció fokozódásával magyaráznak [22]. Igen kis mennyiségben megjelenik az anyatejben is, a csecsemő metforminterhelését az anya testsúlyra korrigált dózisa <0,5\%-ának, 0,13-0,28 mg közöttinek találták [22].

Nem tartozik a farmakokinetikához, a teljesség kedvéért azonban megemlítjük, hogy - a fenti adatokra való tekintettel - a metformin terhesség alatti teratogén kockázatát, terhességi kimenetelt befolyásoló kockázatát több vizsgálatban (Metformin in Gestational Diabetes [MiG], MiG: The Offsprings Follow-Up [MiG TOFU] [23], a 2011-ben indult, még zajló Metformin in Obese Nondiabetic Pregnant Women [MOP]) [1, 24] elemezték, illetve elemzik. A már befejezett vizsgálatok nem igazoltak érdemi kockázatfokozó hatást, a részletekre itt nem térhetünk ki. A hatóanyagot az FDA terhességi B kategóriájúként tartja nyilván (humán teratogenitási adatok nem igazoltak).

\section{A metformin farmakokinetikájának és farmakodinamikájának molekuláris mechanizmusai}

A metformin kis molekula (molekulasúlya 165,62 gramm/mol [18]). Bár kísérletes megfigyelések szerint nagy koncentrációban diffúzióval átjuthat a membránokon, humán vonatkozásban ez nem volt megerősíthető: nagy fokban hidrofil természete folytán [25] szövetekbe való bejutása csak transzporter molekulák segítségével lehetséges (1. ábra).

In vitro megfigyelések szerint a bél lumenéből döntő részben a plazmamembrán-monoamin-transzporter (PMAT) segítségével jut az enterocytákba. E folyamatban kisebb mértékben az organikus kationtranszporter (OCT) -3 is részt vesz. Az enterocytákból az interstitialis 


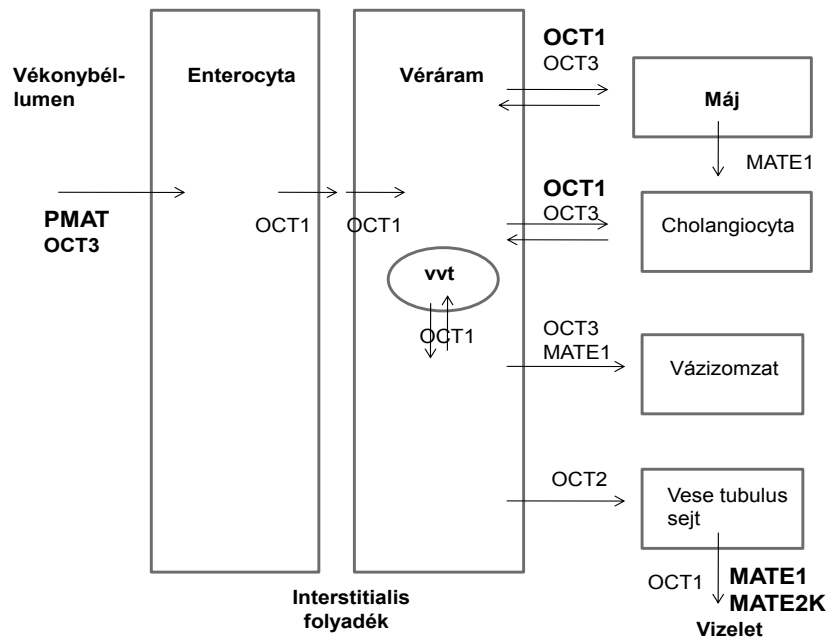

1. ábra

A metformin szervezetbeli transzportjában szerepet játszó fehérjék $[6,16]$

A transzporterrövidítések jelentését lásd a rövidítésjegyzékben A nagyobb betúvel és vastagabb szedéssel jelzett szállítófehérjék az adott szövet vonatkozásában nagyobb jelentőséggel rendelkeznek az ugyanott feltüntetett más transzporterekhez képest

folyadékba, illetve a véráramba kerül, mindkettőbe az OCTl révén. Vércukorcsökkentő hatásának elsődleges területe a máj: eredménye a glükoneogenezis és következményesen a hepaticus glükózkibocsátás csökkenése. A hepatocytákba jutását döntően az OCTl irányítja, alárendelt jelentőséggel azonban abban az OCT3 is közremúködik. Szemben az előzőekkel, a máj-véráram transzport kétirányú, azaz a transzporterek a metformint mindkét irányba szállítják. Ugyanezt igazolták a cholangiocyták esetében is. Ennek jelentősége ez idő szerint nem tisztázott $[1,2,6,25]$.

Több megfigyelés támasztja alá, hogy metformin rövid tartamú iv. adása kevéssé hatékony, mint azonos dózis orális bejuttatása. Ezek az adatok azt támasztják alá, hogy a metformin intestinalis jelenléte a vércukorcsökkentő hatás szempontjából meghatározó jelentőségú [14]. Mivel biohasznosulása csak 50\%-os, továbbá, a bélben intakt állapotú marad - egyszeri orálisan bevitt dózis 30\%-a a széklettel ürül -, a distalis vékonybél nyálkahártyájában a plazmáét akár 300-szorosan meghaladó koncentrációja mérhető. Ha tehát biztosítható, hogy a bevitt gyógyszermennyiség nagyobb része a distalis vékonybélbe kerüljön, az intestinalis hatások, a GLP-1 és a PYY termelődésének serkentése, erősíthetők. E lehetőség elérésére több megoldás is kínálkozik. Az egyik a nagy pro dosi adagok alkalmazása, amelyek a transzportfehérjéket - időlegesen - „telíteni” képesek. A másik olyan formuláció kidolgozása, amely csak bizonyos $\mathrm{pH}$ nál oldódik és válik belőle a metformin szabaddá. Így fejlesztették ki az IR-szerkezetű hatóanyagot eudragyt polimerekkel körülvevő, már említett DR készítményváltozatot. A külső burok egyfajta „enteralis köpenyként” biztosítja, hogy a hatóanyag kioldódása csak $\mathrm{pH}<6,5$-nél kezdődjön, ami a proximális vékonybéltől aboralis bél- szakaszok sajátja. E DR-készítményváltozat az első vizsgálatok szerint hatékonyabb éhomi és étkezés utáni (postprandialis - pp) vércukorcsökkenést biztosít, mint az azonos hatóanyag-tartalmú IR-változat [14, 15].

Hosszú időn keresztül vita tárgyát képezte, hogy mi a metformin közvetlen molekuláris támadáspontja a májban. A legutóbbi időkig az volt az általános nézet, hogy az AMPK, esetleg a liver kináz B (LKB) -1-AMPK jelátvivő út $[2,6,16,25,26]$. Újabb adatok szerint - bár az AMPK meghatározó jelentőségű az aktiválódó jelátviteli útban és a létrejövő génexpresszió, illetve fehérjefunkció-változások végső soron az AMPK aktiválódásának következményei -, elsődleges célorganelluma a mitochondrium, azon belül pedig a mitochondrialis légzési lánc komplex (mitochondrial respiratory chain complex - MRCC) -1 [2, 6, 25].

Állatkísérletes megfigyelések szerint a hepatocytákban nagyságrenddel nagyobb metforminkoncentráció mérhető, mint más szövetekben. Ez megmagyarázza, miért itt a legkifejezettebb a szer hatása. A különbség részben annak következménye, hogy a bélből felszívódó hatóanyag a vena portae-n keresztül közvetlenül a májba jut. Másik összetevője a májsejtek magas OCTl-tartalma, míg e speciális transzportfehérje a metformin szempontjából kitüntetett jelentőségű más szöveti területeken (vázizomzat, vese) csak kisebb mértékben fordul elő [25].

Az AMPK a sejt energiaszenzora és energiahomeostasisának irányítója. Aktivitása fokozódik, ha az ATP-tartalom csökken (azaz nő az ADP/ATP és/vagy az AMP/ ATP arány). Aktiválódásakor gátlódik az ATP katabolizmusa, így a ciklikus AMP-képződés is. $\mathrm{Ez}$ - jelátviteli láncolat közvetítésével - a gluconeogeneticus génexpresszió csökkenését eredményezi. Másrészrôl gátlódik a lipogenezis egyik kulcsenzime, a szterolreguláló elemeket kötő fehérje-1 (sterol regulatory element-binding protein-1 - SREBP1) expressziója, egyidejúleg fokozódik a hepatocyták zsírsav-oxidációja is. Mindez a koleszterin- és a trigliceridszintézis csökkenéséhez vezet [25]. A harmadik fontos jelátviteli út a glükogenezist serkentő és a sejtproliferációban szerepet játszó TORC2A (TORC: TOR containing complex, az mTOR [mammalian target of rapamycin] közvetítésével érvényesülő jelátviteli út egyik komponense) gátlása. A metformin fóbb hatásait és azok szöveti tényezőit az 1. táblázatban foglaljuk össze.

Az AMPK - lényegét tekintve szerin-treonin kináz katalitikus $\alpha$, valamint két ( $\beta$ és $\gamma$ ) regulatorikus alegységből felépülő heterotrimer szerkezetü fehérje. Az alegységek sztöchiometrikus egységet képeznek. Valamennyi alegységnek legalább két izoformja van, egymással való társulásuk szövetspecifikus. Állatkísérletes adatok szerint a katalitikus alegységek funkciója is különbözik egymástól, ami eltérő AMPK-választ eredményez [26]. Az AMPK aktiválódásának első lépése az AMP $\gamma$-alegységhez történő kötődése. Ez alloszterikus szerkezetmódosuláshoz és az $\alpha$-alegység következményes aktiválódásához 


\begin{tabular}{|c|c|c|c|}
\hline Szerv & Támadáspont & Múködésváltozás & Mérhető paraméter \\
\hline \multicolumn{4}{|c|}{ A szénhidrát-anyagcserét érintő hatások } \\
\hline Máj & $\begin{array}{l}\text { MRCCl- } \\
\text { AMPK } \uparrow \\
\text { glükagonreceptor- } \\
\text { aktivitás } \downarrow \\
\text { cAMP-tartalom } \downarrow\end{array}$ & $\begin{array}{l}\text { glükoneogenezis } \downarrow \\
\text { HGO } \downarrow \\
\text { glükoneogenezis } \downarrow \\
\text { HGO } \downarrow\end{array}$ & $\begin{array}{l}\text { éhomi vércukor } \downarrow \text { * } \\
\text { éhomi vércukor } \downarrow \text { * }\end{array}$ \\
\hline Bél & $\begin{array}{l}\text { AMPK } \uparrow(?) \\
\text { M3 receptoraktiváció? }\end{array}$ & $\begin{array}{l}\text { GLP-1-elválasztás } \uparrow \\
\text { PYY-elválasztás } \uparrow * *\end{array}$ & éhomi és pp. vércukor $\downarrow$ \\
\hline Izomszövet & AMPK $\uparrow$ & GLUT4-aktivitás $\uparrow$ & éhomi és pp. vércukor $\downarrow$ \\
\hline Hypothalamus & AMPK $\downarrow * * *$ & orexigén neuronaktivitás $\downarrow$ & $?$ \\
\hline \multicolumn{4}{|c|}{ A zsiranyagcserét érinto" hatások } \\
\hline $\begin{array}{l}\text { Máj } \\
\text { Izomszövet }\end{array}$ & $\begin{array}{l}\text { MRCCl- } \\
\text { AMPK } \uparrow \\
\text { MRCCl- } \\
\text { AMPK } \uparrow\end{array}$ & $\begin{array}{l}\text { SREBP-aktivitás } \downarrow \\
\text { zsírsav-oxidáció } \uparrow \\
\text { zsírsav-oxidáció } \uparrow\end{array}$ & $\begin{array}{l}\text { VLDL-koleszterin } \downarrow \\
\text { trigliceridszintézis } \downarrow\end{array}$ \\
\hline \multicolumn{4}{|c|}{ Föbb pleiotrop hatások } \\
\hline Szívizom & $\begin{array}{l}\text { AMPK } \uparrow \\
\\
\text { PI3K } / \text { AKT } \uparrow \\
\text { PAI } 1 \downarrow\end{array}$ & $\begin{array}{l}\text { lipidszintézis } \downarrow \\
\text { zsírsav-oxidáció } \uparrow \\
\text { DAG/PKC aktivitás } \downarrow \\
\text { oxidatív stressz } \downarrow \text { (?) } \\
\text { eNOS-foszforiláció } \uparrow \\
\text { mPTP } \downarrow \\
\text { fibrinolysis } \uparrow\end{array}$ & $\begin{array}{l}\text { kísérletes körülmények } \\
\text { között ischaemia } \\
\text { szövetkárosító hatása } \downarrow \\
\text { NO-szintézis } \uparrow * * * *\end{array}$ \\
\hline Endothel & $\begin{array}{l}\text { AMPK } \uparrow \\
\text { AGE-képződés } \downarrow\end{array}$ & $\begin{array}{l}\text { eNOS-foszforiláció } \uparrow \\
\text { NO-szintézis } \uparrow \\
\text { ICAM-, VCAM-képződés } \downarrow\end{array}$ & $\begin{array}{l}\text { endotheldependens } \\
\text { vasodilatatio } \uparrow(?)\end{array}$ \\
\hline
\end{tabular}

Jelölések (a rövidítések között az alábbiakban csak a rövidítésjegyzékben nem szereplőket tüntetjük fel):

$\uparrow=$ fokozódik; $\downarrow=$ csökken; cAMP = ciklikus AMP; DAG $/ \mathrm{PKC}=$ diacil-glicerol/proteinkináz $\mathrm{B} ; \mathrm{eNOS}=$ endothelialis nitrogén-monoxid-szintáz; HGO = $($ hepatic glucose output) hepaticus glükózkibocsátás; $\mathrm{M} 3=$ muszkarinreceptor; $\mathrm{mPTP}=$ (mitochondrial permeability transition pore) mitochondrialis permeabilitás faktor; $\mathrm{NO}=$ nitrogén-monoxid, PI3K/AKT = foszfatidil-inozitol 3' kináz/proteinkináz B; ? = kérdéses hatás; * = az éhomi vércukor csökkenését a pp. vércukor csökkenése is kíséri; ${ }^{* *}=$ a PYY szerepe e tekintetben kérdéses; ${ }^{* *}=$ GLP-1-hatás eredménye; ${ }^{* * *}=$ kísérletes körülmények között igazolva.

vezet. A metformin AMPK-aktiváló hatása csak intakt sejten érvényesül. Ugyanakkor csökkent hatását kimutatták LKBl-AMPK génkiütött állatokban is, ami az AMPK-tól független - a hatás tekintetében alárendelt jelentőségü - aktivációs mechanizmust is valószínúsít [2]. Ennek egyik lehetőségét a glükagonreceptor, és ennek révén, a glükagon indukálta ciklikus AMP-képződés, illetve jelátviteli útjainak gátlása jelenti [25].

$\mathrm{Az}$ izomszöveti hatások is az AMPK aktivációján keresztül érvényesülnek. A jelátviteli lánc a GLUT4 glükóztranszporter múködésének fokozódását és a glükózfelvétel következményes javulását eredményezi. Egyidejûleg fokozódik a zsírsav-oxidáció is [6]. E folyamatok pontos molekuláris háttere - szemben a májbeli reakcióutakkal - sok tekintetben tisztázatlan. Figyelmet érdemel, hogy egy, a kérdéssel kapcsolatban megjelent adato- kat feldolgozó közlemény szerint, míg a metformin hepaticus glükózkibocsátást csökkentő és éhomi glükózclearence-t növelő hatása egyértelmü, az egész test inzulinérzékenységét fokozó tulajdonságát eddig nem sikerült minden kétséget kizáróan alátámasztani [27].

E megfigyelésnek ugyanakkor ellentmond a hyperinsulinaemia mérséklődése alkalmazása során (ami önmagában a vércukorszint és így a glükotoxicitás csökkenésével aligha magyarázható, abban az inzulinhatás javulása is szerepet kell, hogy játsszon). Korábban a metformin hatásai között tartottuk számon a lipolízis mérséklődését is. Újabb adatok tükrében ez az előzőekhez képest alárendelt jelentőségü.

A hypothalamusban kimutatható AMPK az energiafelvétel (és így a testsúly) molekuláris szabályozó tényezője. Az orexigén hormonok (ghrelin, Agouti-szerü fe- 
hérje [Agouti-related protein - AgRP], neuropeptid [NP] Y) aktiválják, az inzulin és a leptin gátolják múködését.

A gátlóhatás a zsírsavszintézis fokozásán és egy specifikus jelátvivő fehérje, az mTOR aktiválásán keresztül érvényesül. Az mTOR az orexigén $\mathrm{AgRP} / \mathrm{NPY}$ neuronok gátlódását, az anorexigén proopiomelanokortin (POMC)/kokain-amfetaminszerú termék (cocaine-amphetamine related transcript [CART]) irányította neuronok aktiválódását eredményezi [28]. A metformin hypothalamicus AMPK-aktivációt csökkentő hatása feltehetően a GLP-1 közvetítésével érvényesül. E hormon elválasztásának fokozódása ellensúlyozhatja a hyperinsulinaemia csökkenésének ellentétes irányú befolyását, az összefüggés közelebbi részletei azonban ez idő szerint feltáratlanok. Egyes újabb adatok a metformin direkt AMPK aktiváló hatását támasztják alá a hypothalamusban is.

A metformin GLP-1-elválasztást fokozó mechanizmusának pontos biokémiai háttere még nem tisztázott, abban több mechanizmus részvétele igazolt. Így az AMPK-é is - az enzim aktivátorai in vitro serkentették a GLP-1 képződését -, úgy túnik azonban, hogy talán nagyobb jelentőségú a muszkarinreceptor-aktiváció, illetve a gastrin releasing hormon termelődésének fokozódása [29]. Legújabban kimutatták, hogy a metformin fokozza az inkretin - a GLP-1 és a GIP - receptorok expresszióját a béta-sejtben, s feltételezik, hogy ez is az AMPK közvetítésével érvényesül. A megfigyelések azonban némiképp ellentmondóak, más vizsgálatban ugyanis azt találták, hogy az AMPK e hatása elsősorban alacsony glükózkoncentráció esetén jelentkezik [30].

A metformin anyagcserehatásainak lezárásaként a 2 . táblázatban foglaljuk össze a szervezetbeli transzportjában szerepet játszó fehérjéket és azok szöveti megoszlását.

Nem tisztázott a hatóanyag gastrointestinalis mellékhatásainak - gastritisszerú panaszok, gyomorgödri nyomás, nausea, lágy széklet, hasmenés - háttere és mechanizmusa sem. A készítmény alkalmazásának korai szakaszában felvetették, hogy csökkenti a szénhidrátok bélből történő felszívódását, s a panaszok lehetséges okaként felmerült a visszamaradó szénhidrátok szerepe. Későbbi vizsgálatok nem erősítették meg a molekula e felszívódáscsökkentő tulajdonságát, így a feltevés is túlhaladottá vált. E tekintetben előrelépést hozott, amikor felismerték, hogy szerkezete rokonságot mutat az 5-hidroxi-triptamin- (HT-) 3 receptoragonistákéval. Tanulmányozni kezdték ezért a metformin 5-HT-3 receptors stimuláló és serotinin release-t befolyásoló természetét [31]. Míg - neuralis és nem neuralis mechanizmusú - szerotoninserkentő hatása megerősíthető, az 5-HT-3 receptor részvétele kizárható volt [32]. A mellékhatás pontos magyarázatával tehát még adós a farmakológia. Ma még arra sem adható válasz, miért jelentkezik e mellékhatás a készítményt szedók egy részében korán és intenzíven, másokban miért nem, valamint, hogy miért jelentkezhetnek e panaszok akár hosszas panaszmentes metforminszedést követően is.

\section{A metformin AMPK-LKBl út részvételével érvényesülő pleiotrop hatásai}

A metformin számos, vércukorcsökkentő hatásától független, „pleiotrop” tulajdonságát igazolták. Az alábbiakban csak ezek néhány kiemelt területével foglalkozunk, azokkal, amelyekben az előzőekben áttekintett folyamatok szerepe igazolt vagy feltételezhető. Így nem érintjük a szer plazminogénaktivátor-inhibitor-1-termelődését $[1,33]$, adhéziós faktorok (ICAM-1, VCAM-1) képződését visszaszorító $[1]$, néhány vizsgálatban megfigyelt intestinalis lokális gyulladáscsökkentő és citokintermelődést mérséklő [11], a bél microbiota-összetételét [34], valamint az adaptív és veleszületett immunválaszt potenciálisan befolyásoló [34] hatásait. (A teljesség kedvéért meg kell azonban említenünk, hogy ez utóbbiban az AMPK részvételét valószínúsítik [35].)

A zsíranyagcsere kedvező változását - az össz- és LDLkoleszterin-, valamint a trigliceridtartalom csökkenését az előzőekben röviden már érintettük. Emberen nem igazolódott az AMPK-SREBPI tengely múködésváltozása alapján felvetett előnyös hatása steatosis hepatisban, noha egyes állattörzseken - ob/ob egéren, illetve LKB 1 génkiütött egéren - ezzel ellentétes megfigyelések ismertek [2]. Mind több adat támasztja alá viszont kedvező vese-, endothel- és keringési rendszert érintő hatásait.

Állatkísérletes vizsgálatokban a metformin csökkentette a hypoxia által indukált egyik tényező (HIF-1) génjének expresszióját, $s$ mérsékelte a vesesejtek oxigénszükségletét. E hatás az AMPK-tól függetlennek bizonyult, ugyanis a jelátvivő út tényezőinek génkiütött modelljeiben is érvényesült. Mivel ismereteink szerint a tartós hypoxia és a HIF-1 termelődésének következményes fokozódása a diabeteses nephropathia egyik kulcseleme, a megfigyelések megerősítése új kezelési stratégiát jelenthet. Más vizsgálatokban a metformin csökkentette az oxidatív stressz és a fokozódó reaktívoxigén-species(ROS-) termelés indukálta lipidperoxidációt, valamint a transzformáló növekedési faktor (TGF) $\beta$ hatására bekövetkező tubulointerstitialis fibrosist. Podocyta-sejttenyészetben ugyancsak megfigyelték AMPK-t aktiváló és ROS-képződést csökkentő természetét [2].

Állatkísérletben, Wistar egereken biokémiai paraméterekkel és szövettani megfigyelésekkel egyaránt alátámaszthatóan mérsékelte a gentamycin nephrotoxicus hatását [36], valamint a hypoxia indukálta endothel-, illetve podocytapusztulást. E hatásai alapján egyes vélemények renoprotectiv természetünek tartják [37].

A metformin AMPK-aktiváló természetét hypoxiás/ reoxigenatiós szívmodelleken is igazolták. Az egészséges szív oxidatív foszforilációhoz szükséges energiája 60 90\%-át zsírsav-oxidációból fedezi (a koszorúér károsodá- 
sakor az arány mindinkább eltolódik a glükózfelvétel és -hasznosítás irányába). Jól ismert, hogy a zsírsav-oxidáció ATP-igénye nagyobb, mint a glükózé, így annak viszszaszorítása csökkenti az energiaszükségletet, mérsékli hypoxiakárosító hatását. Experimentális körülmények között a metformin helyreállította a hypoxia folytán eltolódott lipid/glükóz arányt. Egy másik vizsgálatban cardiomyocyta-sejtkultúrában a metformin csökkentette a proapoptotikus fehérjék termelődését [2].

$\mathrm{Az}$ addigi ismeretek tükrében meglepő eredményt hozott a 19691 T2DM-es személy bevonásával folytatott Reduction of Atherothrombosis for Continued Health (REACH) tanulmány. A metformint szedő betegek mortalitása ugyanis alacsonyabb volt (6,3\% [95\% konfidenciaintervallum, CI: $5,2-7,4 \%]$ ), mint a metformint nem kapó csoportban (9,8\% [95\% CI: 8,4-11,2\%], esélyhányados 0,76 [95\% CI: 0,65-0,89]). A különbség azon alcsoportokban is megerősíthető volt - szívelégtelenségben szenvedők, beszúkült vesemúködésűek -, akik esetében a metformin adása az ismert óvatossági rendszabályok folytán ellenjavallt lett volna $[2,38]$.

A metformin polycystás ovarium szindrómában (PCOS) segítheti az ovuláció bekövetkeztét, helyreállíthatja a periódusok ciklicitását, csökkentheti a plazma androgéntartalmát $[2,6,7]$. Hatása - például a granulosasejtek androgéntermelése esetében - részben az AMPK-LKBl reakcióut közvetítésével, részben közvetve, a plazma inzulintartalmának csökkenésén keresztül érvényesül. Ez utóbbi állhat a citokróm P450 (CYP) 17, a 3-béta-hidroxi-szteroid-dehidrogenáz és a szteroidogén akut reguláló fehérje (steroidogenic acute regulatory protein - StAR) aktivitáscsökkenésének hátterében [2]. A metforminadást kísérő számos további előnyös változás - például a vetélések számának csökkenéséhez vezető endometrialis androgénreceptorszám-csökkenés, a PAI1 és plazma-endothelin-1-tartalom mérséklődése - létrejöttének pontos biokémiai háttere még nem tisztázott, feltehetően valamennyi az inzulinhatás javulásával áll összefüggésben [2].

A metformin közvetlen hatását támasztja alá a Pregnancy in PCOS tanulmány azon adata, miszerint az LKBl gén egyes polimorfizmusaival rendelkezőkön ritkábban észlelték az ovuláció rendszeressé válását metformin adása után [2].

A metformin - egyes daganatok esetében megfigyelt, de általánosságban meg nem erősített - tumorkockázatot csökkentő természete is részben közvetlenül, részben az inzulinszint csökkenésén keresztül érvényesülő hatás. Előbbi hátterében e tekintetben is az AMPK-aktiváció áll. Ezt támasztja alá, hogy AMPK génkiütött, illetve AMPK-gátlókkal előkezelt állatmodelleken a metformin antiproliferatív hatása nem vagy csak csökkent mértékben érvényesül.

Az AMPK aktiválódása gátolja az mTOR jelátvivő tényező expresszióját, ami további sejtproliferációt serkentő tényező, a TORCl aktivációjának (foszforilálódásának) elmaradását eredményezi. Az mTOR termelődését egyébként az inzulinszerű növekedési faktor (IGF) -1 is fokozza, a hyperinsulinaemia mérséklődése így az IGF-1-en keresztül közvetve is gátolja a folyamatot. Legújabban igazolták a metformin AMPK-tól független, közvetlen TORCl-gátló hatását is [1,2]. A folyamatok a leírtaknál jóval összetettebbek, több tényezőt felvonultatók, a kiragadott részletek csupán az AMPK-LKBl reakcióút lehetséges szerepének megvilágítását szolgálják.

\section{A metformin hatását befolyásoló polimorfizmusok és gyógyszer-interakciók}

Korábbi vizsgálatok mind a metformin farmakokinetikájában, mind klinikai hatékonyságában esetenként jelentős eltéréseket találtak. Felszívódása és hatásai molekuláris mechanizmusainak, tényezői genetikai hátterének megismerésével, utóbbiak polimorfizmusainak igazolásával mára ezen eltérések magyarázhatóvá váltak. E génpolimorfizmusok - egy nukleotidot érintő károsodások ( single nucleotid polymorphisms - SNP) - közül a szer farmakokinetikáját, hatékonyságát és a szervezetből történő ürülését érintők a legjelentősebbek [2, 6, 16, 25].

2. táblázat A metformin transzportjában szerepet játszó fehérjék, génjük és szöveti előfordulásuk $[6,16]$

\begin{tabular}{|c|c|c|}
\hline A transzporter & Génje & Szöveti lokalizáció \\
\hline OCTl & SLC22A3 & $\begin{array}{l}\text { enterocyták luminalis felszíne } \\
\text { enterocyták interstitialis felszíne } \\
\text { hepatocyták sinusoidalis } \\
\text { (basolateralis) felszíne } \\
\text { proximalis és distalis } \\
\text { vesetubulus sejtek } \\
\text { vázizomzat } \\
\text { mellékvese* }\end{array}$ \\
\hline OCT2 & SLC22A2 & $\begin{array}{l}\text { vese tubulus sejtek basolateralis } \\
\text { membránja }\end{array}$ \\
\hline OCT3 & SLC22A3 & $\begin{array}{l}\text { hepatocyták sinusoidalis } \\
\text { (basolateralis) felszíne } \\
\text { mellékvese* } \\
\text { vázizomzat }\end{array}$ \\
\hline PMAT & SLC29A4 & $\begin{array}{l}\text { enterocyták luminalis felszíne } \\
\text { vese-epithelsejtek apicalis } \\
\text { felszíne** }^{*}\end{array}$ \\
\hline MATEl & SLC47Al & $\begin{array}{l}\text { hepatocyták ductalis } \\
\text { felszíne } * * \\
\text { vese proximalis tubulussejtek } \\
\text { apicalis felszíne } \\
\text { pancreas alfa-sejtek* }\end{array}$ \\
\hline MATE2K & SLC47A2K & $\begin{array}{l}\text { vese proximalis tubulussejtek } \\
\text { apicalis felszíne }\end{array}$ \\
\hline
\end{tabular}

*Élettani szerepe ez idő szerint nem tisztázott.

**Állatkísérletekben a metformin reabszorpciójában játszott szerepét mutatták ki, emberen e folyamat nem igazolt.

***A metformin biliaris transzportjában való részvételét tételezik fel, a megfigyelések adatai azonban ellentmondóak. 
A metformin farmakokinetikáját befolyásoló polimorfizmusok többsége az OCT-fehérjéket érinti, amelyek az oldott anyagszállító fehérjék (solute carrier family - SLC) családjába, annak 22A csoportjába tartoznak (a többi transzportfehérje is e nagy családba tartozik) (2. táblázat). A metformin szöveti transzportjában szerepet játszó mindhárom változat több variánsát azonosították. Az OCTl esetében például 4 SNP-t írtak le, amelyek mindegyike a „vad” (eredeti) változathoz képest magasabb metformin-plazmakoncentrációt eredményezett (görbe alatti területként meghatározva). Elhúzódóbbá vált a hepaticus transzport, ugyanakkor emelkedett a metforminclearence is. Az OCT2 esetében 3 polimorfizmus azonosítására került sor. A mutált allélt hordozókon lényegében a fentiekkel egyező eltéréseket azonosítottak. A MATEl és a MATE2K esetében eddig nem volt a metformin farmakokinetikájával kapcsolatba hozható polimorfizmus azonosítható [6]. Az eddigi adatok szerint a farmakokinetikát érintő genetikai módosulások a metformin klinikai hatékonyságát érdemben nem befolyásolják.

$\mathrm{Az}$ OCTl több olyan variánsát (R61C, G401S, 420del, G465R [6], rs622342 [16]) is kimutatták, amelyek csökkentették a metformin hepaticus hatását. A MATEl rs2289669 G>A variánsa ugyanakkor több vizsgálat eredménye szerint fokozta a szer $\mathrm{HbA}_{\mathrm{lc}}$-vel jellemzett glykaemiás hatékonyságát (más vizsgálatban azonban a hatást nem találták szignifikáns mértékűnek) [6, 16]. A csökkent, illetve fokozott hatás kifejezettebb volt homozigóták esetében. Közöltek olyan eseteket is, amikor mindkét mutált gén jelenléte kimutatható volt. Mindkettő homozigóta variánsa esetén a metforminhatás kifejezetten csökkent. (Mivel mindkét károsodás a gén intronrészén helyezkedik el, a metforminhatás megváltozásának pontos magyarázata nem ismert [16].) E polimorfizmusoktól függetlenül az OCTl hepaticus expressziója akár háromszoros mértékben is különbözhet az egyes egyedek között, ami igen eltérő metforminhatást eredményezhet [16]! E megfigyelések arra hívják fel a figyelmet, hogy a metformin szükséges dózisát minden esetben egyénre szabottan, a klinikai hatékonyság figyelembevételével kell meghatározni.

Az OCTl variánsai a metformin renalis ürülését is befolyásolhatják. Az eddigiek során e transzporter génjének két olyan polimorfizmusát írták le, amelyek a természetes, „vad" változaténál alacsonyabb aktivitású fehérje képződését eredményezték. Olyan személyeken, akik a két kóros SNP közül csak az egyik tekintetében bizonyultak heterozigótának, a metformin kiválasztása érdemben nem változott. Mindkettő heterozigóta jelenléte esetén a clearence változott, azonban a kis esetszám (4 közölt eset) alapján érdemi állásfoglalás még nem lehetséges. Leírták a MATEl, illetve a MATE2K egy-egy polimorfizmusát is, azonban ez sem járt az elimináció érdemi módosulásával [16].

Több gyógyszer esetében kimutatták a metformin transzportjában szerepet játszó tényezőkkel való interak- ció lehetőségét. A cimetidin például a kationtranszporterek szubsztrátja: napi 400 mg-os dózisban az OCT2-vel, illetve a MATEl-gyel való interakciója révén gátolhatja a metformin renalis ürülését. Az antimaláriás, illetve protozoonbetegségekben használatos pyrimethamin in vitro vizsgálatban gátolta a MATEl és a MATE2K aktivitását. A felsoroltak bázikus természete alapján felmerült hasonló kémiai viselkedésú gyógyszerek (antihisztaminok, antidepresszánsok, opioid analgetikumok) metforminürülést befolyásoló potenciális hatása, míg metformin is csökkentheti a szervezetből nagyrészt változatlanul ürülő bázikus természetű molekulák (például amfetaminszármazékok) eliminációját [16]. Ez utóbbiak vonatkozásában konkrét adatok egyelöre nem ismeretesek, együttes alkalmazásukkor azonban e lehetőséget mérlegelni tanácsos. In vitro vizsgálatban kimutatták a glinidek és a rosiglitazon OCTl-gátló hatását, az észlelés klinikai relevanciáját illetően azonban nincs adat [16].

Részben a szinergista vércukorcsökkentő hatások erősítése, részben a beteg-együttmúködés javítása céljából számos antidiabetikum metforminnal kombinált fix öszszetételü változata is forgalomba került. Ezek mindegyike esetében vizsgálták az összetevők egymás farmakokinetikáját és szervezetbeli metabolizmusát befolyásoló hatását, s az minden esetben kizárható volt.

\section{A molekuláris hatások megismeréséből levonható gyakorlati következtetések}

Az utóbbi időben - a T2DM kezelésében hosszú ideje betöltött helyének [3-5], bővülő indikációs körének [1, 7,8 ] és az adása biztonságos voltával kapcsolatos újabb ismereteknek megfelelően [2, 23-25, 37, 39] - rohamosan nő a metforminnal foglalkozó közlemények száma. Alkalmazása iránt megnőtt a társszakmák érdeklődése is [7, 9-11, 34, 38, 40]. Munkánk szándékoltan nem e kérdéseket kívánta áttekinteni, hanem hatásai molekuláris hátterére és a megismerésükből levonható következtetésekre kívánta ráirányítani a figyelmet.

$\mathrm{Az}$ áttekintett adatok megerősítik, hogy a metformin hatása - a felszívódását, szövetekbe jutását segítő, eliminációjában részt vevő transzportfehérjék esetenkénti genetikai és következményes funkcionális eltéréseiból adódóan - individuálisan változó. Az ajánlott dózistartományon belül ezért a glykaemiás paraméterek gondos monitorozásával meg kell határozni az adott betegen alkalmazandó leghatékonyabb dózist.

A diabetest kísérő társbetegségek, állapotok kezelésére bevezetendő gyógyszerek esetében gondolni kell a már alkalmazott szerekkel kialakuló esetleges interakciók lehetőségére. Ilyen esetekben metformint is tartalmazó vércukorcsökkentő kezelés esetén szükség lehet a metformindózis ismételt meghatározására.

A metforminvérszint monitorozása ma még nem része a mindennapi gyakorlatnak, noha különböző eljárások alkalmazása vizsgálatok tárgyát képezi [16]. E tekintetben a plazmából és a teljes vérből történő meghatározás 
- a vörösvértestek elhúzódó metforminturnoveréből adódóan - jelentős eltérést eredményezhet. Úgy tünik, a jelentôsen ingadozó plazmaszinttel szemben utóbbi lehet a meghatározásra alkalmasabb. A megbízható vérszint-monitorozás kidolgozása növelheti a metforminalkalmazás biztonságát beszúkült vesemúköóesú személyeken is [16].

Az alkalmazásával kapcsolatos - egyre szélesebb körüvé váló - „pleiotrop” előnyökre való tekintettel ellenjavallat/intolerancia hiányában adását a T2DM egész szakaszában fenn kell tartani, ső́t érdemi eredményt nem hozó életmódkezelés után, annak elemeit megtartva, érdemes már praediabetesben megkezdeni. Molekuláris hatásai még részletesebb feltárása bővítheti alkalmazása javallatait és segíthet adása még biztonságosabbá válásában.

Anyagi támogatás: A cikk megírása anyagi támogatásban nem részesült.

A szerző a kézirat végleges változatát elolvasta és jóváhagyta.

Érdekeltségek: A szerzőnek a kézirat elkészítésével kapcsolatban nincsenek érdekeltségei.

\section{Irodalom}

[1] Rojas, L. B., Gomes, M. B.: Metformin: an old but still the best treatment for type 2 diabetes. Diabetol. Metab. Syndr., 2013, 5(1), 6. http://www.dmsjournal.com/content/5/1/6

[2] Viollet, B., Guigas, B., Sanz Garcia, N., et al.: Cellular and molecular mechanisms of metformin: an overview. Clin. Sci., 2012, 122(6), 253-270.

[3] Gaál, Zs., Gerö, L., Hidvégi, T., et al.: Diagnosis, treatment and care of diabetes mellitus in adults. Guideline of the Hungarian Diabetes Association, 2014. [A diabetes mellitus kórismézése, a cukorbetegek kezelése és gondozása a felnőttkorban. A Magyar Diabetes Társaság szakmai irányelve, 2014.] Diabetol. Hung., 2014, 22(Suppl. 1), 2-84. [Hungarian]

[4] Inzucchi, S. E., Bergenstal, R. M., Buse, J. B., et al.: Management of hyperglycemia in type 2 diabetes, 2015: a patient-centered approach: Update to a Position Statement of the American Diabetes Association and the European Association for the Study of Diabetes. Diabetes Care, 2015, 38(1), 140-149.

[5] Garber, A. J., Abrahamson, M. J., Bazilay, J. I., et al.: Consensus statement by the American Association of Clinical Endocrinologists and American College of Endocrinology on the comprehensive type 2 diabetes management algorythm -2016 executive summary. Endocr. Pract., 2016, 22(1), 84-113.

[6] Gong, L., Goswami, S., Giacomini, K. M., et al.: Metformin pathways: pharmacokinetics and pharmacodynamics. Pharmacogenet. Genomics, 2012, 22(11), 820-827.

[7] Naderpoor, N., Shorakae, S., de Courten, B., et al.: Metformin and lifestyle modification in polycystic ovary syndrome: systematic review and meta-analysis. Hum. Reprod. Update, 2015, 21(5), 560-574. Corrigendum, 2016, 22(1), 1-2.

[8] Sussman, J. B., Kent, D. M., Nelson, J. P., et al.: Improving diabetes prevention with benefit based tailored treatment: risk based reanalysis of Diabetes Prevention Program. BMJ, 2015, 350, h454.
[9] Oner, G., Ozcelik, B., Ozgun, M. T., et al.: The effects of metformin and letrozole on endometriosis and comparison of the two treatment agents in a rat model. Hum. Reprod., 2010, 25(4), 932-937.

[10] Foda, A. A., Aal, I. A.: Metformin as a new therapy for endometriosis, its effects on both clinical picture and cytokines profile. Middle East Fertil. Society J., 2012, 17(4), 262-267.

[11] Koh, S. J., Kim, J. M., Kim, I. K., et al.: Anti-inflammatory mechanism of metformin and its effects in intestinal inflammation and colitis-associated colon cancer. J. Gastroenterol. Hepatol., 2014, 29(3), 502-510.

[12] Wheaton, W. W., Weinberg, S. E., Hamanaka, R. B., et al.: Metformin inhibits mitochondrial complex I of cancer cells to reduce tumorigenesis. eLife, 2014, 3, e02242.

[13] Nakano, M., Inui, A.: Metformin and incretin-based therapies up-regulate central and peripheral adenosine monophosphateactivated protein affecting appetite and metabolism. Indian $\mathrm{J}$. Endocrinol. Metab., 2012, 16(Suppl. 3), S529-S531.

[14] Buse, J. B., DeFronzo, R. A., Rosenstock, J., et al.: The primary glucose-lowering effect of metformin resides in the gut, not the circulation: results from short-term pharmacokinetic and 12week dose-ranging studies. Diabetes Care, 2016, 39(2), 198205.

[15] Song, R.: Mechanism of metformin: a tale of two sites. Diabetes Care, 2016, 39(2), 187-189.

[16] Grabam, G. G., Punt, J., Arora, M., et al.: Clinial pharmacokinetics of metformin. Clin. Pharmacokinet., 2011, 50(2), 81-98.

[17] Pandit, V., Pai, R. S., Yadav, V., et al.: Pharmacokinetic and pharmacodynamic evaluation of floating microspheres of metformin hydrochloride. Drug Dev. Ind. Pharm., 2013, 39(1), 117-127.

[18] FDA: Metformin hydrochloride. http://www.fda.gov/ohrms/ dockets/dailys/02/May02/053102/80047le6.pdf

[19] Timmins, P., Donabue, S., Meeker, J., et al.: Steady-state pharmacokinetics of a novel extended-release metformin formulation. Clin. Pharmacokinet., 2005, 44(7), 721-729.

[20] Shah, A. D., McHargue, C., Yee, J., et al.: Intravenous contrast in patients with diabetes on metformin: new common sense guidelines. Endocr. Pract., 2016, 22(4), 502-505.

[21] Andreucci, M., Solomon, R., Tasanarong, A.: Side effects of radiographic contrast media: pathogenesis, risk factors, and prevention. BioMed Res. Int., 2014, 2014, Article ID 741018.

[22] Eyal, S., Easterling, T. R., Carr, D., et al.: Pharmacokinetics of metformin during pregnancy. Drug Metab. Dispos., 2010, $38(5), 833-840$.

[23] Rowan, J. A., Rush, E. C., Obolonkin, V., et al.: Metformin in Gestational Diabetes: The Offspring Follow-Up (MiG TOFU): body composition at 2 years of age. Diabetes Care, 2011, 34(10), 2279-2284.

[24] Feig, D. S., Moses, R. G.: Metformin therapy during pregnancy. Good for the goose and good for the gosling too? Diabetes Care, 2011, 34(10), 2329-2330.

[25] Rena, G., Pearson, E. R., Sakamoto, K.: Molecular mechanism of action of metformin: old or new insights? Diabetologia, 2013, $56(9), 1898-1906$

[26] Shackelford, D. B., Shaw, R. J.: The LKBl-AMPK pathway: metabolism and growth control in tumor suppression. Nat. Rev. Cancer, 2009, 9(8), 563-575.

[27] Natali, A., Ferrannini, E.: Effects of metformin and thiazolidinediones on suppression of hepatic glucose production and stimulation of glucose uptake in type 2 diabetes: a systematic review. Diabetologia, 2006, 49(3), 434-441.

[28] Rosso, P., Fioramonti, M., Fracassi, A., et al.: AMPK in the central nervous system: physiological roles and pathological implications. Res. Rep. Biol., 2016, 7, 1-13.

[29] Mulherin, A. J., Oh, A. H., Kim, H., et al.: Mechanisms underlying metformin-induced secretion of glucagon-like peptide-l from the intestinal L cell. Endocrinology, 2011, 152(12), 46104619 . 
[30] Tajima, K., Shirakawa, J., Togashi, ., et al.: AMPK is involved in the regulation of incretin receptors expression in pancreatic islets under a low glucose concentration. PloS ONE, 2013, $8(5)$, e64633.

[31] Cubeddu, L. X., Bönisch, H., Göthert, M., et al.: Effects of metformin on intestinal 5-hydroxytryptamine (5-HT) release and on 5-HT3 receptors. Naunyn Schmiedebergs Arch. Pharmacol., 2000, 361(1), 85-91.

[32] Hoffmann, I. S., Roa, M., Torrico, F., et al.: Ondansetron and metformin-induced gastrointestinal side effects. Am. J. Ther., 2003, 10(6), 447-451.

[33] Batchuluun, B., Sonoda, N., Takayanagi, R., et al.: The cardiovascular effects of metformin: conventional and new insights. J. Endocrinol. Diabetes Obes., 2014, 2(2), 1035

[34] Forslund, K., Hildebrand, F., Nielsen, T., et al.: Disentangling type 2 diabetes and metformin treatment signatures in the human gut microbiota. Nature, 2015, 528(7581), 262-266.

[35] Bai, A., Ma, A. G., Yong, M., et al.: AMPK agonist downregulates innate and adaptive immune responses in TNBS-induced murine acute and relapsing colitis. Biochem. Pharmacol., 2010, $80(11), 1708-1717$.
[36] Amini, F. G., Rafieian-Kopaei, M., Nematbakbsh, M., et al.: Ame liorative effects of metformin on renal histologic and biochemical alterations of gentamicin-induced renal toxicity in Wistar rats. J. Res. Med. Sci., 2012, 17(7), 621-625.

[37] Nasri, R. H.: Renoprotective effects of metformin. DARU J. Pharmaceutical Sci., 2013, 21(1), 36.

[38] Roussel, R., Travert, F., Pasquet, B., et al.: Metformin use and mortality among patients with diabetes and atherothrombosis. Arch. Intern. Med., 2010, 170(21), 1892-1899.

[39] Eurich, D. T., Weir, D. L., Majumdar, S. R., et al.: Comparative safety and effectiveness of metformin in patients with diabetes mellitus and heart failure: systematic review of observational studies involving 34,000 patients. Circ. Heart Fail., 2013, 6(3), 395-402.

[40] Inzucchi, S. E., Lipska, K. J., Mayo, H., et al.: Metformin in patients with type 2 diabetes and kidney disease: a systematic review. JAMA, 2014, 312(24), 2668-2675.

(Winkler Gábor dr., Budapest, Diós árok 1-3., 1125 e-mail: gabor.winkler@janoskorhaz.hu)

\title{
MEGHívó
}

\section{A Szent János Kórház és Észak-budai Egyesített Kórházak Tudományos Bizottsága tisztelettel meghívja az érdeklődőket a következő tudományos ülésére.}

\author{
Időpont: 2016. június 16. (csütörtök) 14.00 óra
}

\section{Helyszín: Szent János Kórház Auditóriuma - 1125 Budapest, Diós árok 1-3. \\ Téma: „Mesterséges táplálás: interdiszciplináris betegellátási feladat - Neurológiai és gasztroenterológiai vonatkozások"}

Üléselnök: Prof. Dr. Jánosi András

Minden érdeklődőt szeretettel várunk! 